the icebreaker Sedor in the Arctic, the crew of which was reported to have been taken off the icebound vessel by the icebreaker Joseph Stalin on January 13. The Sedov commenced her drift on October 23, 1937. The book being prepared for press tells the story of the Sedov's unprecedented drift. It contains articles by I. D. Papanin, head of the Northern Sea Route Administration and leader of the North Polar Expedition on the drifting icefloe of 1937-38, and by Prof. N. N. Zubov, and diaries of members of the Sedov's crew.

\section{Clough Memorial Research Fund}

The Clough Memorial Research Fund of the Edinburgh Geological Society was instituted in 1935 for the purpose of encouraging. geological research in Scotland and the north of England; the north of England is defined as comprising the counties of Northumberland, Cumberland, Durham, Westmorland and Yorkshire. Under the terms of administration of the Fund, a sum of approximately $£ 30$ is available annually. Applications for grants are invited for the period April 1, 1939, to March 31, 1940. These applications should state the nature of the research to be undertaken and the amount of grant desired. Applications must be in the hands of the Secretary, Clough Research Fund Committee, Edinburgh Geological Society, Synod Hall, Castle Terrace, Edinburgh, not later than March 1.

\section{Royal College of Physicians: Lectures}

THE following lectures have been arranged by the Royal College of Physicians to be delivered at the College, Pall Mall East, London, at 2.30 p.m. : Mitchell Lecture (postponed from 1939), Dr. F. G. Chandler, "Some Observations on the Diagnosis and Treatment of Pulmonary Tuberculosis" (February 7) ; Milroy Lectures, Dr. R. E: Smith, "Acute Infectious Diseases at School" (February 13 and 15) ; Goulstonian Lectures, Dr. W. D. W. Brooks, "The Pathology and Treatment of Pulmonary Tuberculosis" (February 22, 27 and 29); Bradshaw Lecture (postponed from 1939), Dr. J. C. Spence, "On the Nature of Disease in Infancy" (March 7); Oliver-Sharpey Lectures, Prof. E. P. Cathcart, "The Mystery of Alimentation"' (March 12 and 14) ; Croonian Lectures, Dr. George Graham, "Recent Advances in Diabetes Mellitus: Aetiology and Treatment" (May 16 and 21).

\section{Royal Aeronautical Society: Lectures}

Arrangements are being made by the Royal Aeronautical Society to resume part of the lecture programme which was postponed on the outbreak of war. It is hoped to arrange definitely for four or five lectures. The first one, on aircraft production, will be given by Mr. H. J. Pollard, on March 12 at 6.0 p.m., in the Institution of Electrical Engineers. Sir Alan Cobham and Mr. Marcus Langley have provisionally agreed to give a joint lecture on flight refuelling in the air; Mr. A. A. Hall on recent theoretical and experimental work on turbulence; Wing Commander T. R. Cave-Brown-Cave on noise and nuisance in aircraft, at dates to be fixed. The Wilbur Wright Lecture will be delivered at the end of May.

\section{The Night Sky in February}

DURING this month, the night shortens in the latitude of London by $1 \frac{3}{4}$ hours. The moon is new on February 8 and full on February 23. Lunar conjunctions with the planets occur as follows: with Venus on February 11d. 21h., with Jupiter on 12d. 14h., with Saturn on 14d. 3h., with Mars on $14 \mathrm{~d}$. $4 \mathrm{~h}$. It will be seen from these conjunctions that the bright planets are a striking feature in the evening skies, enhanced by the presence of the crescent moon. On February 13 at 8 h., Mars, which had overtaken Jupiter on January 7 , is in conjunction with Saturn, while on February 20 at 22h., Venus and Jupiter are in conjunction. On February 28, Mercury is at greatest elongation. ( $18^{\circ}$ east) and should be visible low in the west after sunset, leading the train of five bright planets, in addition to Uranus (stellar magnitude 6) in the constellation Aries. The planet Neptune, which transits about $2 \mathrm{~h}$. in mid-February, approaches the 8th magnitude star, B.D. $+3^{\circ} 2549$ (Lalande 22237) on February 14. The light variation of Algol (total variation mag. $2 \cdot 2-$ mag. $3 \cdot 5$ ) is best seen about $1 \frac{1}{2}$ hours before and after the following epochs : February 8 d. $4 \cdot 5$ h., 11d. 1·3h., 13d. $22 \cdot 1$ h. and 16d. $19 \cdot 0 \mathrm{~h}$.

\section{Announcements}

Prof. Max Borst, professor of morbid anatomy at Munich, has been awarded the Goethe Medal for art and science on the occasion of his seventieth birthday for his work on cancer.

Sir Humphry Rolleston, chairman of the executive committee of the Imperial Cancer Research Fund since 1924, and Sir Thomas Dunhill, sergeantsurgeon to the King, were admitted to the honorary fellowship of the Royal College of Surgeons of England at a meeting of the Council on January 11. Sir Hugh Devine, president of the Royal Australasian College of Surgeons, has accepted the honorary fellowship subject to the condition of personal attendance at the College at some future date.

THe number of births in France, which was $1,022,000$ in 1876 , fell to 750,000 in 1930 and 616,000 in 1939. For the last three years the number of deaths has exceeded the number of births by 14,000 annually.

Dr. Frans VERDoorn, formerly of Leyden, Holland, has now gone to the United States. Dr. Verdoorn controls the following publications : Chronica Botanica, New Series of Plant Science Books, "World List of Plant Science Institutions", "International Address Book of Plant Taxonomists", Annales Bryologici and other bryological publications. All communications concerning these should now be addressed to Dr. Frans Verdoorn, Chronica Botanica Co., c/o the Arnold Arboretum, Jamaica Plain, Mass., U.S.A. 